\title{
The Mediating Role of Social Competition Identity Management Strategy in the Predictive Relationship between Susceptibility to Social Influence, Internet Privacy Concern, and Online Political Efficacy
}

\author{
Juneman Abraham ${ }^{1}$ and Murty Magda Pane ${ }^{2}$ \\ ${ }^{1}$ Bina Nusantara University, Psychology Department, Jakarta, Indonesia \\ juneman@binus. edu \\ ${ }^{2}$ Bina Nusantara University, Character Building Development Center, Jakarta, Indonesia \\ murty.pane@gmail.com
}

\begin{abstract}
There are few psychotechnological researches in political world in Indonesia, whereas Indonesia will enter "Year of Politics" by General Election which will be held in 2014. This research aimed at examining the hypothesis of predictive correlation, at the individual level, between susceptibility to social influence, internet privacy concern (as predictor variables) and online political efficacy (as the dependent variable). This research hypothesized that the relationship between the variables is mediated by online identity management strategy in the form of social competition. This research employed questionnaire to gain variables data. Participants of this research were 214 undergraduate students of Bina Nusantara University, Jakarta (106 males, 108 females). Result of this research shows that five of seven proposed hypotheses are supported by empirical data. Implications of the result of this research for online system development for political activities are discussed in the end of this article.
\end{abstract}

Keywords: Online efficacy, politics, identity management, social influence, privacy.

\section{Introduction}

By the rapid use of online social media to gain political purposes, today it becomes urgent to identify variables taking role in predicting online political efficacy. There are numbers of factors known influence online political efficacy. They are successful past experience (including satisfaction with the experience) in using internet as a political instrument, the nature (quantity and quality) of online interaction among members in a political group, type of social media use (information, entertainment, interaction), as well as quality of access (access location and years online) [1,2]. This research assumes that online political self-efficacy is influenced by identity management strategy in the form of social competition--defined as continued engagement in 
the conflict. The concept of identity management is borrowed from Niens and Cairns [3]. According to Tajfel, in: Niens and Cairns [3], identity management strategy is a self-identification strategy of an individual in his/her group "to cope with the perceived outcomes of social comparisons (with his/her out-group)" in order to maintain self-esteem and self-image. Political world is a world which is full of conflict dynamics related to identity, either conflicts among individuals, between individuals and groups, or among groups. Monroe, in: Bernstein [4], stated that conflicts reflect the existence of psychological assumptions concerning how social identity constructed, either actively or passively. Related to that case, referring to the theories of social conflict, conflict is an inherent part of politics [5]. Based on this idea, the author builds the first hypothesis (H1), "The higher an individual uses identity management strategy of social competition, the higher his/her online political efficacy will be".

Furthermore, the author hypothesizes that susceptibility to social influence and various aspects of information privacy concern influence individual's online political efficacy. Bobier had conducted a psychometric analysis and found out that there are two factors of susceptibility to social influence, i.e. principled autonomy and social adaptability [6]. An individual having high principled autonomy is a kind of individual who has less possibility to give conformity response, but has more possibility to give correct responses on critical trials. An individual having high social adaptability is an individual who has more possibility to give conformity response, but less possibility to give correct responses on critical trials. The author presumes that an individual who tends to conform to his/her in-group will exactly shows high social competition to his/her outgroup; the other way around, individual who is more autonomous or independent will shows low social competition toward his/her out-group. Thus, second hypothesis (H2) of this research is "The higher principled autonomy of an individual, the lower identity management of social competition will be", and third hypothesis (H3) is "The higher social adaptability of an individual, the higher identity management of social competition will be".

Social competition can be limited by the individual's privacy concern. The ground idea is that social competition in politics is often accompanied with techniques containing ethical problems from light to heavy, such as the case of tapping the phones of Indonesian public officials, including the President of Indonesia done by intelligent agencies working for Australia [7]. Sims and Gehan through their empirical research also found that online competitions (in the field of economics) often have excesses of information misuse and privacy violation [8]. This reality means that individuals who are competitive and who have high online political efficacy are possibly individuals who have less attention (or: more tolerable) to privacy issues. The author employs three dimensions of contextual model of Internet Users' Information Privacy Concerns (IUIPC) by Malhotra, Kim, and Agarwal, i.e.: (1) Risk beliefs, (2) Perception of errors corrections of privacy practices, and (3) Perception of unauthorized secondary use of personal information [9].

Based on the aforementioned idea, the author hypothesizes (H4, H5), "The higher risk beliefs and perception of unauthorized secondary use of personal information, the lower identity management strategy in the form of social competition in the online world" also (H6) that "The higher perception of errors corrections of privacy 
practices, the higher identity management strategy in the form of social competition in the online world". By integrating $\mathrm{H} 1$ to H6, the author builds a hypothetical model as seen on Fig. 1. This model stated that (H7): "There is a nomological network among variables mentioned above which can explain high or low level of individual's online political self-efficacy".

\section{Methods}

Participants of this research were 214 undergraduate students of Bina Nusantara University, Jakarta (106 males, 108 females), whose mean of age is 19.35 years old and standard deviation of age is 1.678 years old. The data of this research was analyzed by using path analysis. This research used a questionnaire containing seven scales as an instrument to gain the data of the participants.

This research employed quantitative, predictive correlational design. The research data were processed with LISREL 8.8 program. Measurement specification is as show in Table 1. Online Political Self-efficacy scale consists of nine items. The guideline to fill this scale is as follows: "Please rate how certain are you that you can do the things discussed below by choosing the appropriate response." Examples of the items are: (1) Use social media applications to express your political views; (2) Express coherently your political ideas to other online. Identity Management Strategy (Social Competition) scale consists of four items. Examples of the items are: (1) I want my online community to demonstrate that it is the superior one; (2) I want my online community to demonstrate that it is culturally superior. Principled Autonomy scale consists of five items. Examples of the items are: (1) I am willing to stand up for what I believe, even if I lose some friends as a result; (2) I would be willing to take a public stand regarding my beliefs, even if it meant being dropped out or going to jail. Social Adaptability scale consists of nine items. Examples of the items are: (1) I have deliberately, falsely, agreed with someone because I knew I would have to work with them in the future; (2) I have publicly agreed with something I didn't really believe because it would make it easier to keep working with a person. Risk Beliefs scale consists of four items. Examples of the items are: (1) In general, it would be risky to give information to online companies; (2) There would be high potential for loss associated with giving information to online firms (including Facebook, Twitter, Google, etc). Perception of Unauthorized Secondary Use of Personal Information consists of four items. Examples of the items are: (1) Online companies should not use personal information for any purpose unless it has been authorized by the individuals who provided information; (2) When people give personal information to an online company for some reason, the online company should never use the information for any other reason. Perception of Errors Corrections scale consists of four items. Examples of the items are: (1) All the personal information in computer databases should be double-checked for accuracy, no matter how much this cost; (2) Online companies should have better procedures to correct errors in personal information. 
Table 1. Measurement specification

\begin{tabular}{|c|c|c|c|c|}
\hline Variable measured & $\begin{array}{l}\text { Source of } \\
\text { scale adap- } \\
\text { tation }\end{array}$ & $\begin{array}{l}\text { Cronbach's } \\
\text { Alpha } \\
\text { (Reliability) }\end{array}$ & Response scales & $\begin{array}{c}\text { Corrected } \\
\text { item-total } \\
\text { correlations } \\
\text { (Validity) }\end{array}$ \\
\hline Online political efficacy & Perilla [1] & 0.895 & $\begin{array}{l}\text { Strongly Unsure } \\
\text { (score of 1) to } \\
\text { Strongly Sure } \\
\text { (score of } 6 \text { ) }\end{array}$ & $0.366-0.778$ \\
\hline $\begin{array}{l}\text { Social competition identity } \\
\text { strategy }\end{array}$ & $\begin{array}{l}\text { Niens and } \\
\text { Cairns [3] }\end{array}$ & 0.751 & \multirow{6}{*}{$\begin{array}{l}\text { Strongly Dis- } \\
\text { agree (score of } \\
\text { 1) to Strongly } \\
\text { Agree (score of } \\
6 \text { ) }\end{array}$} & $0.406-0.640$ \\
\hline Principled autonomy & \multirow[t]{2}{*}{ Bobier [6] } & 0.680 & & $0.397-0.550$ \\
\hline Social adaptability & & 0.672 & & $0.258-0.458$ \\
\hline Risk belief & \multirow{3}{*}{$\begin{array}{l}\text { Malhotra et } \\
\text { al. [9] }\end{array}$} & 0.689 & & $0.366-0.596$ \\
\hline $\begin{array}{l}\text { Perception of unauthorized } \\
\text { secondary use of personal } \\
\text { information }\end{array}$ & & 0.725 & & $0.466-0.596$ \\
\hline $\begin{array}{l}\text { Perception of errors correc- } \\
\text { tions }\end{array}$ & & 0.728 & & $0.411-0.606$ \\
\hline
\end{tabular}

\section{Results and Discussion}

The result of this research shows that overall hypothetical model (H7) is supported by empirical data (Chi-Square $=7.83$, df $=5$, P-value $>0.05$, GFI $>0.90$, RMSEA $<$ 0.10 ) (see Fig. 1). However, the second (H2) hypothesis is supported by the data in term of relationship statistical significance among variables, but not in term of relationship direction since the hypothesis asserts the occurrence of negative correlation, but in fact the author found a positive correlation. This research also found that there is no significant correlation among variables hypothesized in $\mathrm{H} 4$ and $\mathrm{H} 5$.

Based on the empirical data, path analysis shows that social adaptability (susceptibility to social influence/conformity) is able to indirectly predict online political efficacy through the mediation of social competition identity management strategy. This finding is in line with a study conducted by Kaplan, Brooks-Shesler, King, and Zaccaro entitled "Thinking inside the box: How conformity promotes creativity and innovation" [10]. The result of their analysis indicates that conformity is necessary to effectively implement creative ideas--of which creative idea is indeed hugely demanded in the political world. Conformity can facilitate team coordination, information exchange, conflict management, and collective efficacy. This proposition is different from common sense and many other results of researches saying that the success of an innovation can only be generated by the non-conforming team members or those who think divergently. What is often forgotten by the people in this context is that creative idea generations or originations is only a facet of the creative process, and that team's innovation does not only depend on creative ideas production but also depend on realization of the ideas [10]. The realization of the ideas needs conformity to in-group. Conformity does not need to mean stick to any or all group or 
organizational norms, but it means adhere to norms that promote and express team unity. At today's online political life in Indonesia, the finding of this research matches with everyday realities. Online volunteers for Jokowi-Ahok (Current Governor and Deputy Governor of DKI Jakarta, Indonesia) are an effective online team ("cyber troops"; [11]) who show conformity to group norms, although each of them is a creative individual and even has a high education $[12,13]$.

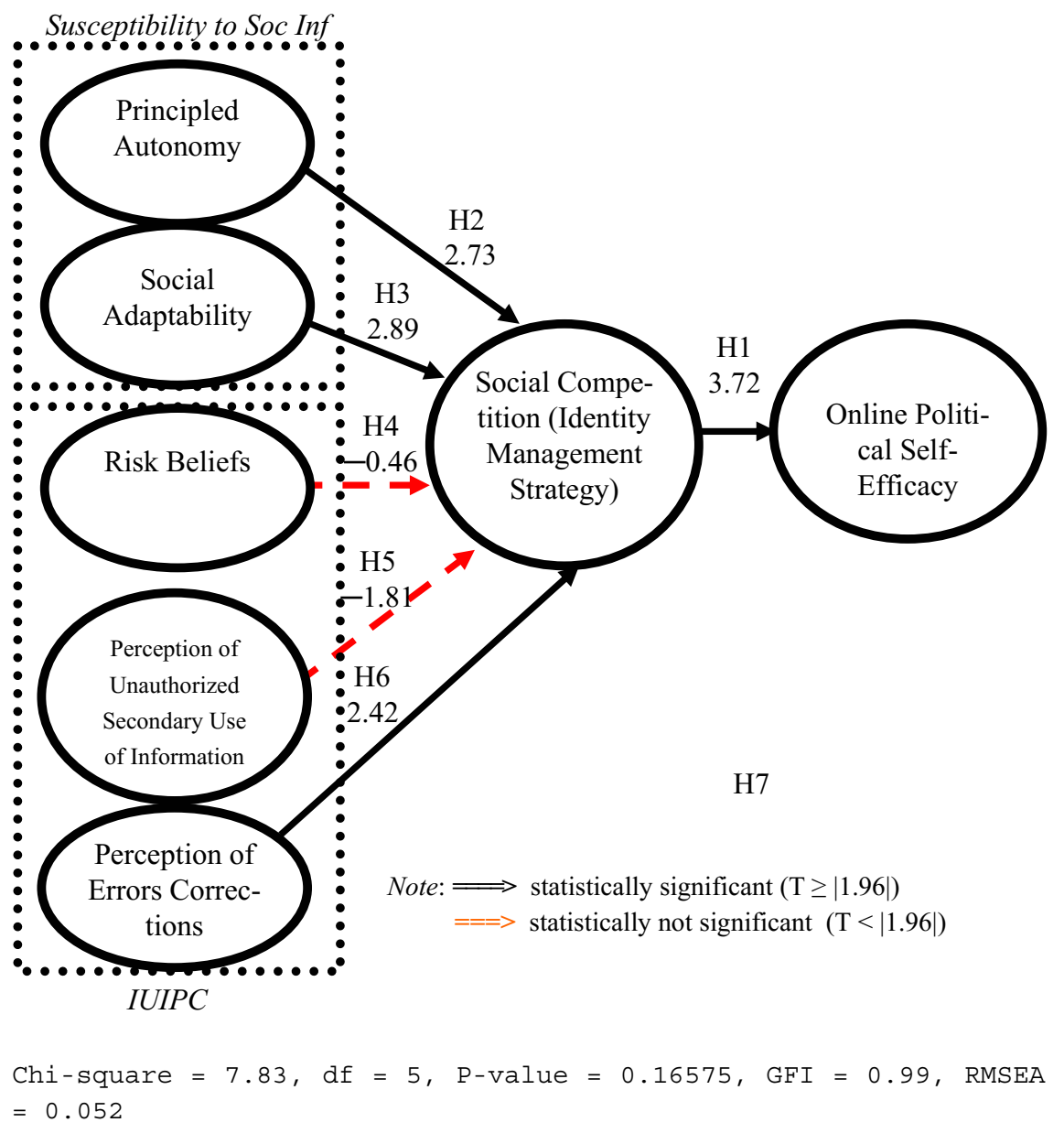

Fig. 1. Research hypotheses and results

This research also found that principled autonomy positively correlate with social competition which later influences online political efficacy. Individual's principled autonomy can be a valuable input for social identity of an individual through one's engagement process toward stories ("master narratives") growing in one's in-group [14]--in this case, his/her online political group. It seems to be enabled by lots of 
attribute diversities of individuals in Jakarta as a megapolitan city and moreover in the online world, which enables an online political group to build their social identity by considering and synthesizing expectation, aspiration, and principles of most of their members. This kind of appreciative thing can latter enhances individual's competitiveness in facing out-group, and next enhances individual's online political efficacy.

This research also found that risk beliefs and perception of unauthorized secondary use of personal data are not essential for participants in determining activities which are related to their identity in the virtual world. There are two explanations related to this matter. First, youth who becomes the participants of this research has undergone desensitization of privacy concern. The desensitization occurs since the individual is faced with the frequent dilemma between inevitable need for data sharing (including political interest) and awareness that there is compensation or trade-off that is the reduction of data privacy $[15,16]$. In the end, the urgent need for data sharing is prioritized, and at the same time people actively or passively monitor policies development concerning solutions to privacy problem. Shacklett added that younger workers are more relaxed about privacy [17]. Second explanation is that youth (who becomes participants of this research), in fact, has the need to move dynamically, back and forth, between risky experiences [18]. Nevertheless, this research found that Perception of Errors Corrections correlates positively with social competition. The author presumes that the positive correlation tends to be resulted by the fact that in political competition, there is a need to access accurate data from political opponents or outgroups. Data integrity is needed by people or party who conduct online political activities in order to be able to determine the precise strategy. It will activate measurable social competition and further will enhance an individual's online political efficacy.

\section{Conclusion}

This research concludes that there is a psychotechnological model which is able to explain an individual's online political efficacy. Online political efficacy can be predicted by (1) Principled autonomy, (2) Social adaptability, and (3) Perception of errors corrections, through the mediating role of social competition identity management strategy. However, internet privacy concerns (risk beliefs and perception of unauthorized secondary use of personal information) are not able to predict it.

In the context of enhancing political participation of the young generation, the result of this research has some important implications. First, since it has been known that online political efficacy is influenced by social competition identity management, thus certain online environments which are intended to be a political arena should be constructed in such a way so that it can facilitate a stimulating, engaging and fun as well as fair competition. This kind of online environment can support political education for the young generation. The author agrees with Priem et al. [19] who emphasize that online customers should be empowered. It has been already clear that online political world has its own customers who continuously grow as time goes by since Indonesia now is entering "Year of Politics" by General Elections 2014. In addition, smart phone and laptop which are usually used to do online activities become 
cheaper. The empowerment can be done by customization of the online system which embodies effective coordination among members of each political group so that members can align mission, strategy, and symbolic instruments before "fighting" by online in expressing political identity and winning online community's heart who become the target of political campaign. Customization of the online system can also be aimed at creating an express and quick profiling concerning constellation of aspiration and expectation of online political group's members. The resulting profiling can be used to encourage social competition in accordance with strength, weakness, and development opportunities of each member. Second, since it has been known that perception of errors corrections influences social competition, online system needs to be design in such a way so that the data accuracy precision reaches the maximum level. Defect in the online system which results in data inaccuracy will decrease healthy social competition and further will decrease online political efficacy.

Third, since it has been known that most of privacy concerns are not significant in influencing identity management strategy--and further online political efficacy, this knowledge should not be unethically used by online system providers as a chance to exploit individual information of online political player. As mentioned above, insignificant correlation is supposedly caused by a condition in which users experience such "helplessness" as they do not have another choice except accept that private information submission by online is a compensation for the service they use. Academicians and practitioners in psychotechnology fields play a role to design online system which is able to enhance bargaining power of online media services' user in such a way so that unnecessary information disclosure will be further minimized.

\section{References}

1. Perilla, A.A.V.: Social Media and Individual and Collective Activism: The Role of Interdependence and Online Political Efficacy. Unpublished PhD dissertation, Communication Arts and Sciences - Media and Information Studies, Michigan State University (2012)

2. Livingstone, S., Helsper, E.: Balancing Opportunities and Risks in Teenagers' Use of The Internet: The Role of Online Skills and Internet Self-efficacy. New Media Society 12(2), 309-329 (2010)

3. Niens, U., Cairns, E.: Identity Management Strategies in Northern Ireland. The Journal of Social Psychology 142(3), 371-380 (2002)

4. Bernstein, M.: Identity Politics. Annu. Rev. Sociol. 31, 47-74 (2005)

5. Acemoglu, D.: Why Not a Political Coase Theorem? Social Conflict, Commitment, and Politics. J. Comp. Econ. 31, 620-652 (2003)

6. Bobier, D.M.: A Measure of Susceptibility to Social Influence: Scale Development and Validation. Unpublished PhD dissertation, Graduate College of The University of Iowa (2002)

7. Akuntono, I.: Sadap Presiden SBY, DPR Tuntut Australia Minta Maaf (July 28, 2013), http: //nasional.kompas.com/read/2013/07/28/1836235/Sadap. Pre siden.SBY.DPR. Tuntut.Australia.Minta.Maaf

8. Sims, A., Gehan, G.: Privacy and the Spam Act in Online Competitions. UABR 12(1), 1-7 (2010) 
9. Malhotra, N.K., Kim, S.S., Agarwal, J.: Internet Users' Information Privacy Concerns (IUIPC): The Construct, the Scale, and a Causal Model. Inform. Syst. Res. 15(4), 336-355 (2004)

10. Kaplan, S., Brooks-Shesler, L., King, E.B., Zaccaro, S.: Thinking Inside the Box: How Conformity Promotes Creativity and Innovation. In: Mannix, E.A., Goncalo, J.A., Neale, M.A. (eds.) Creativity in Groups (Research on Managing Groups and Teams), vol. 12, pp. 229-265. Emerald Group Publishing Limited, Bingley (2009)

11. Andi, R.F.: Mencermati Fenomena Pasukan Dunia Maya Jokowi (November 4, 2013), http://nasional.inilah.com/read/detail/2043655/mencermatifenomena-pasukan-dunia-maya-jokowi\# . Ur-w9-KeaeY

12. Afifah, R.: Saat Anak Muda Berkarya Untuk Jokowi-Ahok (2012), http: / / olahraga.kompas.com/read/2012/06/10/06165790/ function. fopen

13. Ichsan, A.S.: Forum Akademisi IT Menjadi Relawan Jokowi (August 11, 2013), http: / /www.republika.co.id/berita/nasional/jabodetabeknasional/13/08/11/mrd2sk-forum-akademisi-it-menjadi-relawanjokowi

14. Hammack, P.L.: Narrative and the Cultural Psychology of Identity. Pers. Soc. Psychol. Rev. 12, 222-247 (2008)

15. Bakken, D.E.: Data Obfuscation: Anonymity and Desensitization of Usable Data Sets. (IEEE) Security Privacy 2(6), 34-41 (2004)

16. CBSDC: Expert: Individuals 'Desensitized,' 'Numb' to Privacy Threats (June 10, 2013), http: / /washington.cbslocal.com/2013/06/10/expertindividuals-desensitized-numb-to-privacy-threats /

17. Shacklett, M.E.: Younger Workers More Relaxed About Privacy (July 18, 2012) , http: / /www.internetevolution.com/author.asp?section_id=562\& doc_id=247574

18. Răcătău, I.-M.: Adolescents and Identity Formation in a Risky Online Environment: The Role of Negative User-Generated and Xenophobic Websites. Journal of Media Research 3(17), 16-36 (2013)

19. Priem, B., Leenes, R., Kosta, E., Kuczerawy, A.: The Identity Landscape. In: Camenisch, J., Leenes, R., Sommer, D. (eds.) Digital Privacy. LNCS, vol. 6545, pp. 33-51. Springer, Heidelberg (2011) 